\title{
Machinability investigation of Incoloy 825 in high-speed turning under dry conditions
}

\begin{abstract}
${ }^{1}$ Department of Mechanical Engineering, Engineering Faculty, Mersin University, 33343, Ciftlikkoy, Mersin/TURKEY
\end{abstract} e-mail: cinarcagan@mersin.edu.tr, barisbuldum@mersin.edu.tr

\begin{abstract}
The superalloys are hard to machine materials used in critical applications such as aeronautics and aerospace sectors. One of the most important parameters of the machinability tests is the surface roughness values, which enable us to determine the specific properties of the material measured from the surface of the materials being machined. So, this study proposes to advance a depth understanding of surface roughness evolution, of Incoloy 825 material, when is submitted to machining process. The machinability of Incoloy 825 superalloys were investigated by varying different high-speed machining parameters. Three different cutting tools (I, II and III), three different speeds (500, 1000 and $2000 \mathrm{~m} / \mathrm{min}$ ) and three different feed rates $(0.1,0.2$ and $0.4 \mathrm{~mm} / \mathrm{rev})$ were chosen as parameters. The surface quality, chip formation and tool wear outputs of the Incoloy 825 machined workpiece were analyzed and optimum machining parameters were determined. The results indicate that the key parameters impressing the surface roughness, of the Incoloy 825 superalloy, are the cutting speed and feed rate, respectively. Further, the cutting tools investigated have not had a material impact on the surface roughness. The accelerated tool wear is driven by the cutting speeds as well. An overview of the results achieved in this study indicate that the optimal surface roughness value is reached when the following parameters are imposed: tools type: II, cutting speed: $1000 \mathrm{~m} / \mathrm{min}$ and feed: 0.1 $\mathrm{mm} / \mathrm{rev}$.
\end{abstract}

Keywords: Superalloy; Turning; Surface roughness; High-speed; Taguchi method.

\section{INTRODUCTION}

Superalloys are materials that have suitable properties such as superior strength, fatigue and corrosion resistance, and creep resistance at high temperatures, although they are difficult to machining [1-5]. These alloys are opted for products such as space shuttle parts, nuclear reactor and oil refinery components, furnace parts, turbines due to their superior properties [6-10]. All these applications are related to harsh environment (high temperatures and pressures, respectively) working condition.

One of the most important issues to be investigated in the machining industry is the machinability rating of the material, which is also expressed by the difficulty of processing the workpiece under the current conditions. [11-14]. Although it is not only sufficient to have data about the material for efficient machining of the workpiece, it is also important to choose the correct cutting tool suitable for the material to be processed, to determine the machining parameters and to carry out experiments under suitable conditions. As a result of machining parameters which cannot be selected well during the machining stage, the cutting tool will wear faster, causing the workpiece not to be machined properly or the surface quality of the workpiece to deteriorate. This leads to some economic and time losses in the manufacturing sector where competition is quite high $[11,15,16]$. The machinability of super alloy materials is more difficult than lightweight metals such as aluminum and magnesium which have high machinability rating. [17, 18]. Al, $\mathrm{Co}, \mathrm{Zr}, \mathrm{Fe}, \mathrm{Mo}, \mathrm{Nb}$ and $\mathrm{B}$ elements are added to nickel-based superalloys to provide high creep performance, excellent oxidation and corrosion resistance at high temperatures. The nickel-based superalloys have superior mechanical and corrosion resistance, therefore, are widely used in aerospace applications in medium to high-temperature applications. However, it is difficult to process these materials cause their workability properties are low. In these materials, the main concentrate is on the investigation of surface texture, cutting force, tool wear mechanism, and tool life in different machining processes [19-22]. The work by Palanisamy and Selvaraj [23] was made to come up with the most suitable factors for the machining of superalloy (Incoloy $800 \mathrm{H}$ ). They researched the effects of different cutting parameters on the surface characteristic feature of Incoloy 
$800 \mathrm{H}$ material. Joshi et al. [24] examined the impact of turning the Incoloy 800 material in different parameters to the surface quality and tool wear in different environments (dry, minimum quantity lubrication (MQL) and flood) was analyzed. In the experiments performed in MQL environment, the best surface roughness was obtained, and the tool wear was found to be the least. Liu et al. [25] studied the machinability of Incoloy A286. They measured and analyzed surface turning properties, surface properties, and fatigue life at different cutting parameters (shear rate, feed rate, and depth). It has been revealed that the cutting parameters can significantly change the surface texture and surface yield strength, and the workpiece has a more pronounced effect on fatigue life. Eskandari et al. [26] conducted a study to optimize the surface properties and the bulk of the removed material using the GRA method. Eskandari et al., detected the control factors as the depth of cut, feed rate, and cutting speed were selected, and optimum parameter values were determined. Palanisamy et al. [27] investigated the Incoloy $800 \mathrm{H}$ superalloy in different processing parameters of the turning and optimization parameters were carried out. The surface roughness, cutting power and cutting force parameters were minified, the material removal rate was exaggerated. Also, chip morphology were examined. In the study conducted by Palanisamy and Selvaraj [28] was carried out the turning effect over the thermal treated superalloy by employing cryogenic process chemical vapour deposition(CVD)-coated TiAlN tool. The results of thrust, shear, surface roughness, insert temperature, material removal rate, and friction coefficient was obtained. In other studies, surface roughness, microhardness, work hardening, and material removal rates were taken into consideration [29]. Thakur and colleagues enquired the machinability of Incoloy 825 workpiece using different cutting tools. Experiments were performed by determining feed rate and different cutting speeds. The effects of different cutting tools on the tool wear, cutting force, surface roughness, friction coefficient, cutting temperature, chip thickness were investigated [30]. Venkatesana et al. studied the turning of Incoloy $800 \mathrm{H}$ workpiece under different conditions (different concentrations of $\mathrm{Al}_{2} \mathrm{O}_{3}$-added coconut oil) and different machining parameters. Effects of machining parameters on force, wear and surface texture were investigated and appropriate parameters were optimized [31].

Despite large amount of literature for machining of difficult-to-cut materials (such as superalloys, steels, Ti alloys), there is no systematic study concentrated on high speed machining of these materials. Therefore, in this study we present a systematic evaluation to find the optimum parameters when machining Incoloy 825 superalloy, which allows a higher productivity for industrial sector. The evolution of surface roughness was investigated to detect the best input parameters (tools type, cutting speed, and feed rate) and tool wear, and chip formation were characterized accordingly. To reduce the potential matrix protocol, the design of experiments was outlined by applying $\mathrm{L}_{9}$ orthogonal Taguchi method. In this study, the effect of surface roughness, tool wear, and chip formation on the different parameters (tools type, cutting speed, and feed rate) of the Incoloy 825 face turning process was investigated.

\section{MATERIALS AND METHODS}

\subsection{Materials}

Incoloy 825 discs were put into practice for machinability experiments. These discs are $115 \mathrm{~mm}$ and $50 \mathrm{~mm}$. The content of Incoloy 825 is mainly based on $\mathrm{Ni}, \mathrm{Cr}$ and Fe elements. The chemical composition ratios of the materials in the Incoloy 825 superalloy are presented in Table 1. The production phase of the material, solution annealing was performed with water at $1020{ }^{\circ} \mathrm{C}$ for 5 hours. After this process, precipitation hardening was carried out for 2 hours at $750{ }^{\circ} \mathrm{C}$. Before turning, the hardness value of the material was measured as $35.1 \mathrm{HRC}$. The yield strength of the Incoloy 825 superalloy was measured as $771 \mathrm{~N} / \mathrm{mm}^{2}$ and the tensile strength as $1102 \mathrm{~N} / \mathrm{mm}^{2}$. The above-mentioned discs are commercially available from Germany. The experiments were carried out on the same disc.

Table 1. The chemical composition ratios of Incoloy 825 superalloy (wt. \%)

\begin{tabular}{ccccccccccc}
\hline Material & $\mathrm{Ni}$ & $\mathrm{Cr}$ & $\mathrm{Mn}$ & $\mathrm{Cu}$ & $\mathrm{Ti}$ & $\mathrm{Mo}$ & $\mathrm{C}$ & $\mathrm{Si}$ & $\mathrm{Al}$ & $\mathrm{Fe}$ \\
\hline Incoloy 825 & 42.89 & 21.02 & 0.59 & 1.53 & 2.21 & 3.46 & 0.02 & 0.22 & 0.42 & Balance \\
\hline
\end{tabular}

\subsection{Experiments}

The experimental methodology is shown in Figure 1. A Liouy Hsing GNC-450L CNC lathe were used to simulate the face turning process, as depicted in Figure 2. Face turning operations were accomplished by designing different parameters for machining experiments. DNMG 150608 cutting tools were used. The tool 
I was coated with TiAlSiN using the PVD, Tool II was coated $\mathrm{TiCN} / \mathrm{Al}_{2} \mathrm{O}_{3}$ using the CVD and Tool III was TiAlN/TiN using the PVD. Considering the studies in the literature, three different face turning parameters (tools, cutting speed, and feed rate) and three different levels of these parameters were determined. These levels of control factors were selected according to previous studies, experience, and recommendations of the tool manufacturers (Table 2). These level values were adapted to the orthogonal array of Taguchi $\mathrm{L}_{9}$ shown in Table 3, and experiments were started.

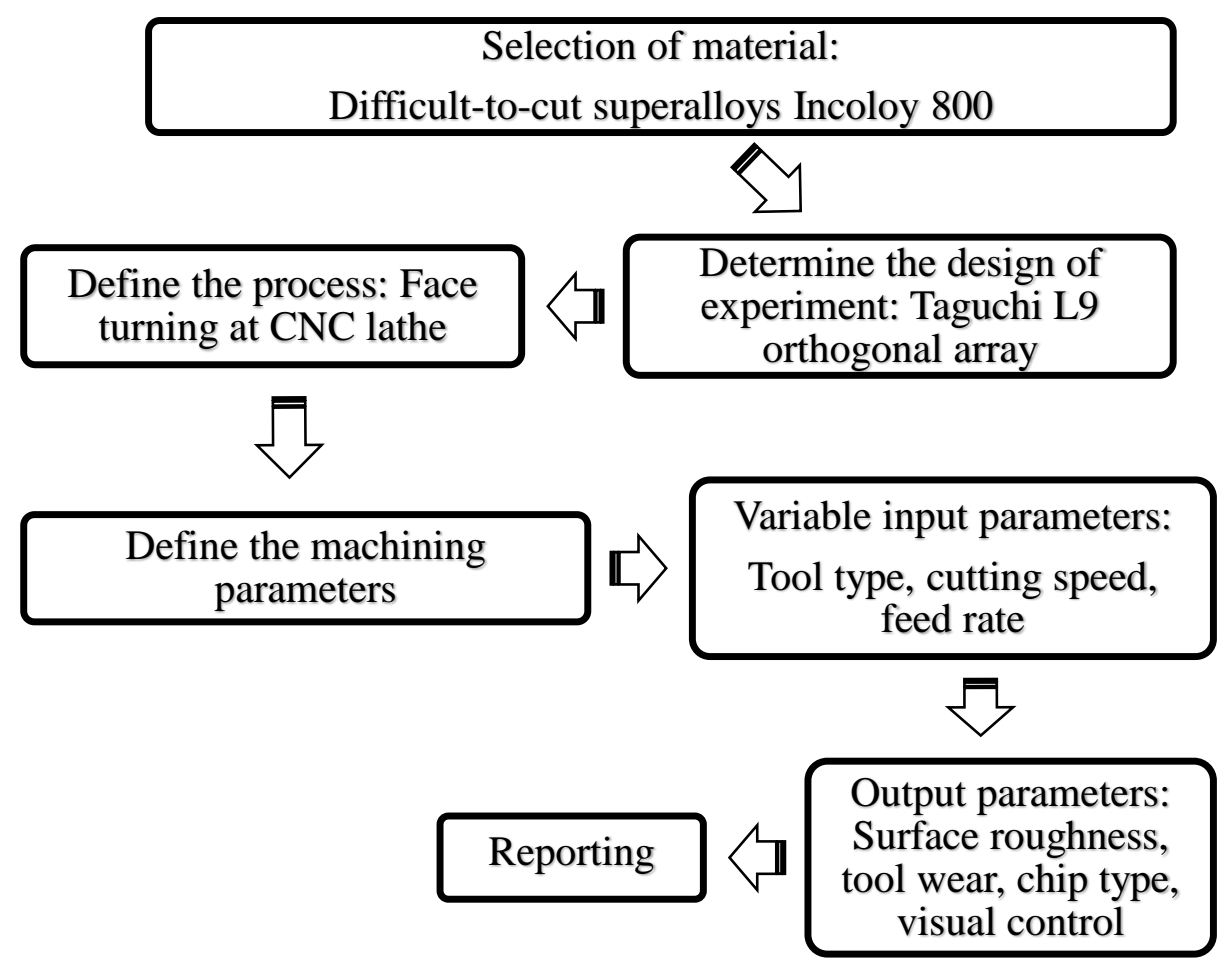

Figure 1. The experimental methodology

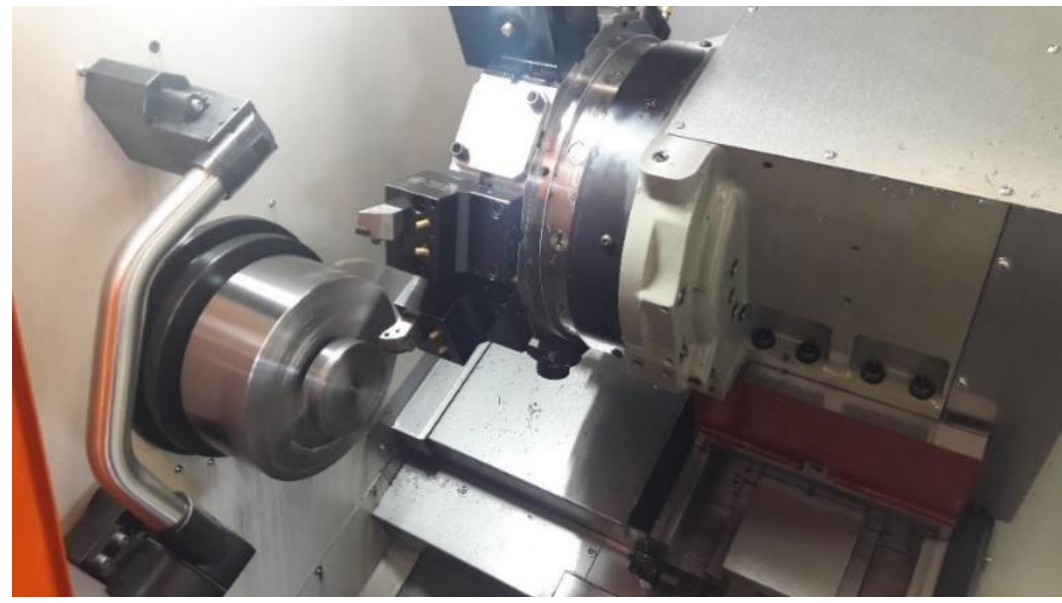

Figure 2. The experimental setup

Taguchi method was taken into consideration while making the experimental design. This is because in traditional experimental designs, especially many experiments have to be performed and it is difficult to apply when the number of processing parameters is increased. Therefore, the Taguchi experimental design method allows more than one factor to be taken into account at the same time, but also provides the optimum result with less experimentation [32-36]. The Taguchi method can reduce the number of experiments without concluding the results [37]. If all the experiments had to be carried out, $3 \times 3 \times 3=27$ experiments would 
have been necessary. The Taguchi method was used to avoid wasting time and material by doing so many experiments, thereby saving $2 / 3$ of time and material.

Table 2. Face turning process parameters and levels.

\begin{tabular}{l|c|c|c|c}
\hline \multirow{2}{*}{ Parameters } & Units & \multicolumn{3}{c}{ Levels } \\
\cline { 2 - 5 } & & 1 & 2 & 3 \\
\hline Tools Type & - & Tool-I & Tool-II & Tool-III \\
\hline Cutting Speed & $\mathrm{m} / \mathrm{min}$ & 500 & 1000 & 2000 \\
\hline Feed rate & $\mathrm{mm} / \mathrm{rev}$ & 0.1 & 0.2 & 0.4 \\
\hline
\end{tabular}

Table 3. Taguchi experimental design

\begin{tabular}{cccc}
\hline Experiments & Tools Type & Cutting Speed & Feed rate \\
\hline 1 & 1 & 1 & 1 \\
2 & 1 & 2 & 2 \\
3 & 1 & 3 & 3 \\
4 & 2 & 1 & 2 \\
5 & 2 & 2 & 3 \\
6 & 2 & 3 & 1 \\
7 & 3 & 1 & 3 \\
8 & 3 & 2 & 1 \\
9 & 3 & 3 & 2 \\
\hline
\end{tabular}

\subsection{Surface roughness}

Surface profiles of the machined workpieces were measured using the Surftest SJ-210 (Mitutoyo), a contactbased profilometer with a $2 \mu \mathrm{m}$ stylus tip radius made of diamond, with a detector type of $60^{\circ}$ and a detector measuring force of $0.75 \mathrm{mN}$, following the JIS'01 guide. The cutting length and the evaluation length were fixed at $0.8 \mathrm{~mm}$ and $4 \mathrm{~mm}$, respectively. The measurement speed is $0.75 \mathrm{~mm} / \mathrm{s}$ and a Gaussian cutoff filter is used. The arithmetic mean surface roughness $\mathrm{Ra}$ and average roughness depth $\mathrm{Rz}$ of each sample were calculated from the average data of the five valid measurements.

\section{RESULTS AND DISCUSSION}

\subsection{Experimental Results}

After experiments with different face turning parameters, the surface roughness values of Incoloy 825 , their standard deviations (SD), and the S/N ratio calculated from these values are depicted in Figure 3 and Table 4.

Table 4. Parameters and surface roughness results and calculated $\mathrm{S} / \mathrm{N}$ ratios

\begin{tabular}{cccccccc}
\hline \multirow{2}{*}{ Experiments } & \multicolumn{4}{c}{ Parameters } & \multicolumn{3}{c}{ Results } \\
\cline { 2 - 8 } & Tools Type & Cutting speed & Feed rate & Ra $(\mu \mathrm{m})$ & $\begin{array}{c}\text { SD for } \\
\text { Ra }\end{array}$ & Rz $(\mu \mathrm{m})$ & S/N Ra \\
\hline 1 & Tool-I & 500 & 0.1 & 0.6005 & 0.0391 & 2.5087 & 4.42974 \\
2 & Tool-I & 1000 & 0.2 & 1.0575 & 0.0162 & 5.0112 & -0.48561 \\
3 & Tool-I & 2000 & 0.4 & 2.3885 & 0.0989 & 14.402 & -7.56250 \\
4 & Tool-II & 500 & 0.2 & 1.2560 & 0.0183 & 4.3008 & -1.97979 \\
5 & Tool-II & 1000 & 0.4 & 1.5630 & 0.0042 & 11,408 & -3.87918 \\
6 & Tool-II & 2000 & 0.1 & 0.5010 & 0.0531 & 2.4355 & 6.00325 \\
7 & Tool-III & 500 & 0.4 & 1.9255 & 0.0770 & 13.349 & -5.69087 \\
8 & Tool-III & 1000 & 0.1 & 0.7320 & 0.0466 & 4.0607 & 2.70978 \\
9 & Tool-III & 2000 & 0.2 & 2.0828 & 0.0360 & 14.001 & -6.37316 \\
\hline
\end{tabular}




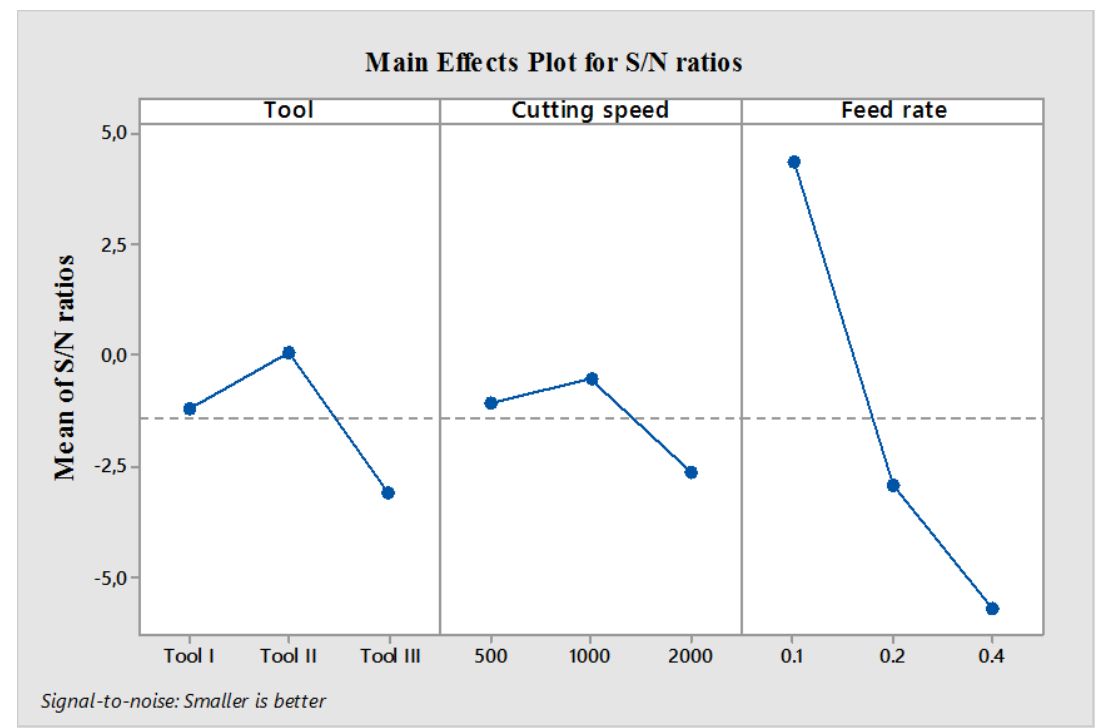

Figure 3. Change of Ra results to calculated $\mathrm{S} / \mathrm{N}$ ratios

The $\mathrm{S} / \mathrm{N}$ ratios of the Ra values obtained in the experiments were calculated. When the graph is examined, it is seen that the Ra values obtained from the experiments on tool II are preferable the other tools. The $\mathrm{Ra}$ value is increased when the cutting speed increases from $1000 \mathrm{~m} / \mathrm{min}$ to $2000 \mathrm{~m} / \mathrm{min}$, though the Ra value decreases from $500 \mathrm{~m} / \mathrm{min}$ to $1000 \mathrm{~m} / \mathrm{min}$. This is because when high cutting speeds are reached, most of the chips move off the tool cutting edge and the heat generated by the high friction causes the chips to accumulate on the tool. Thus, it causes a decrease in surface quality [38-40]. According to these results, the surface quality is the best when the speed is $1000 \mathrm{~m} / \mathrm{min}$. In the study of Morelo et al. [38], It is stated that in order to obtain low surface roughness, the feed rate should be chosen low and the nose radius should be chosen relatively large. In this study, the same nose radius was selected for each tool and it was concluded that the surface roughness was reduced when a low feed rate was selected. Based upon of S/N ratio the optimized faceturning process parameters for accomplishment best Ra are Tool: II, the cutting speed $1000 \mathrm{~m} / \mathrm{min}$ and feed rate: $0.2 \mathrm{~mm} / \mathrm{rev}$

\subsection{Analysis of Variance (ANOVA)}

Thanks to the variance analysis, the factors have an effect on the outcomes by calculating "degrees of freedom (DF), F value, P value, mean squares (MS), sum of squares (SS)" data. The purpose of ANOVA is to determine how the intended factors affect the output values and the factor that has the maximum impact $[41,42]$. According to the applied ANOVA in this study, it is observed that the tools $(8.9 \%)$, the cutting speed $(12.5 \%)$ and feed rate $(74.3 \%)$ play roles in minimizing the surface roughness (Table 5). After the tests applied to the Incoloy 825 workpiece, it turns out that the most notable factor affecting the $\mathrm{Ra}$ value is the feed rate. With the results obtained from the ANOVA F effects on the outputs of the parameters used in turning operations was calculated. In the calculated F value results, the greatest value indicates which parameter has the greatest effect on the outputs. Considering the data in Table 5, it is seen that the feed rate parameter is the most dominant factor affecting the Ra.

For calculations, the equations specified in 1-7 were used. The random change in the factor is measured by the "error sum of squares" (SSE). Depending on the differences between the factors, the variation called factor effect is measured by the "sum of squares between factors" (SSA). The total variability in data measured by total squares (SST) is divided into these two components, as in regression:

$$
\begin{aligned}
S S T & =S S A+S S E \\
S S T & =\sum_{i=1}^{k} \sum_{j=1}^{n}\left(y_{i j}-\bar{y}\right)^{2}
\end{aligned}
$$




$$
\begin{aligned}
& S S A=n \sum_{i=1}^{k}\left(y_{i}-\bar{y}\right)^{2} \\
& S S E=\sum_{i=1}^{k} \sum_{j=1}^{n}\left(y_{i j}-\overline{y_{i}}\right)^{2}
\end{aligned}
$$

where $\mathrm{k}=$ number of factors, $\mathrm{n}=$ number of measurements, $\mathrm{y}_{\mathrm{ij}}=\mathrm{j}$ th measurement of factor $\mathrm{i}, \overline{\mathrm{y}}=$ overall sample mean of all factors, $\bar{y}_{i}=$ sample mean of factor.

Factor mean squares (MSA) and error mean squares (MSE) are obtained by dividing the sum of the corresponding squares by their degrees of freedom. These degrees of freedom also depend on the size of the problem, that is, the number of factors and the number of measurements within the factors. The " $F_{\text {calc }}$ " value is calculated by dividing MSA by MSE.

$$
\begin{gathered}
M S A=\frac{S S A}{k-1} \\
M S E=\frac{S S E}{k(n-1)} \\
F_{\text {calc }}=\frac{M S A}{M S E}
\end{gathered}
$$

Table 5. ANOVA results for surface roughness

\begin{tabular}{lcccccc}
\hline \multicolumn{1}{c}{ Parameters } & DF & SS & MS & F-Value & P-Value & \% Contribution \\
\hline Tools Type & 2 & 0.3363 & 0.16815 & 2.17 & 0.315 & 8.9 \\
\hline Cutting speed (m/min) & 2 & 0.4695 & 0.23474 & 3.03 & 0.248 & 12.5 \\
\hline Feed rate (mm/rev) & 2 & 2.7900 & 1.35902 & 18.00 & 0.053 & 74.3 \\
\hline Error & 2 & 0.1550 & 0.07748 & & & 4.1 \\
\hline Total & 8 & 3.7508 & & & & \\
\hline
\end{tabular}

The feed rate ratio has great performance on turning process. The CNC lathe can fix the feed rate against diameter shifts. In surface roughness, the peaks and valleys depending on cutting tool movement on the surface. The peaks can be removed by the pitch of feed rate. The process parameters should allow optimal the chip removing time from the workpiece. Otherwise, the peaks and valleys appear on the surface as roughness. The other cutting speed parameter also depends on the feed rate. However, a major factor is generally feed rate in the turning process - the tool geometry and tip radius a parameter for defining the feed rate. Incompatible variable choices do not allow suitable cutting results [43-45].

\subsection{Tool Wear}

The images acquired after inspecting the tools used in different face turning parameters are presented in Figure 4. The wear patterns areas were indicated by arrows. When the graphics are examined, it appears that cutting speeds have an important effect on tool wear. As the cutting speeds increase, wear on the tools also increases. Although there is no significant wear at $500 \mathrm{~m} / \mathrm{min}$ and $1000 \mathrm{~m} / \mathrm{min}$ cutting speeds, it is seen that there is significant wear on the tools at $2000 \mathrm{~m} / \mathrm{min}$ cutting speeds. When the surface roughness values and tool wear are examined together, the surface quality deteriorates with the increase in the feed rate. It is seen that cutting speed and different tool tips do not have a significant difference on the surface roughness and tool wear. Figure 4 also supports these comments. 


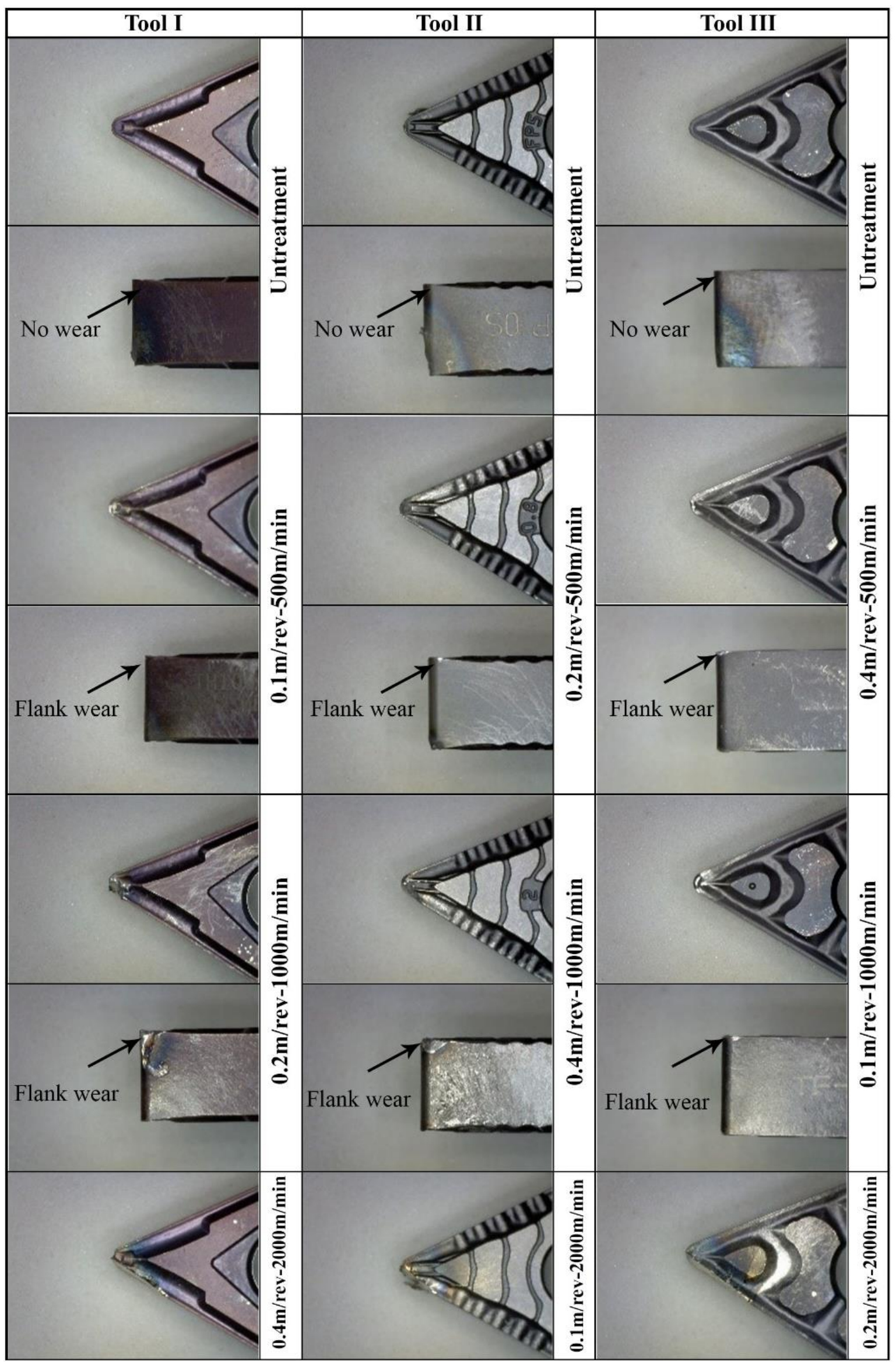




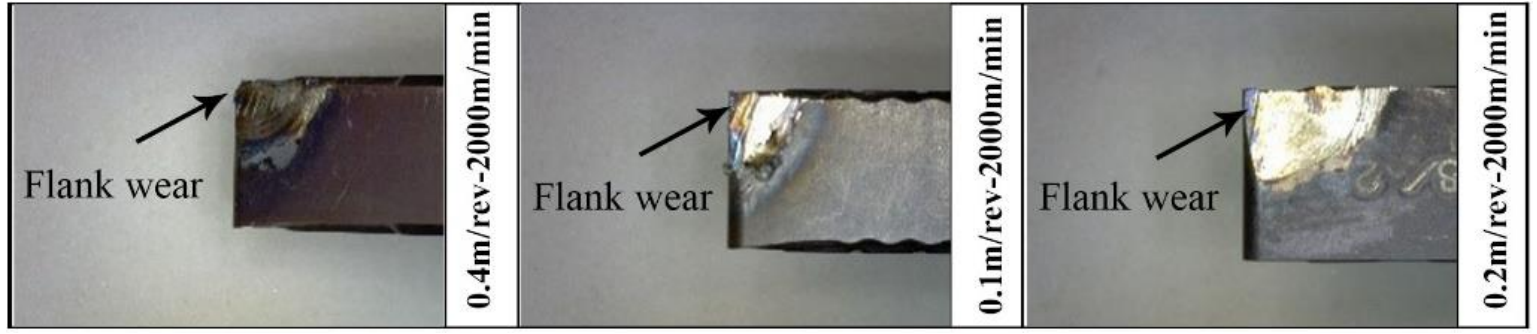

Figure 4. Tool wear images at different face turning conditions

\subsection{Chip Formation}

Chip formation was investigated at different cutting conditions, as shown in Figure 5. The details examined from this figure reveals the heat-induced colour changes during cutting. They were indicated in the chips from experiments no: C2, C3, C5, and C6. These colour changes (from white colour in C1, orange/red colour in $\mathrm{C} 3 / \mathrm{C} 5$ to dark blue colour in C6) indicate the release of excessive temperature on the cutting tool and material [46-48]. The temperature is a factor indicating a direct effect over the material characteristic and life of the insert, in the negative direction. In other experiments, there is a constant flow. However, no colour change was observed on the chips. It has been found that the diameter of the helix geometry formed by the chips is different concerning the feed rate and the cutting speed. The reason for the formation of C6 chips in blue is due to the high temperature in the cutting zone. The light gold colour of the C2, C3 and C5 chips is related to the fact that the temperature in the chip area is higher than normal. The chips of $\mathrm{C} 1, \mathrm{C} 4, \mathrm{C} 7, \mathrm{C} 8$, C9 are silver. These samples show that they are not affected by heat during the chip removal process. In Table 6, the types of chips generated after turning routine are categorized according to ISO 3685 standards [49]. Chip types can be evaluated in three aspects as process health (cutting health and operator safety), surface quality of the processed material, and cutting force assessment for the shape of the chips. Short chips are safer than long chips in terms of process health. Because long chips both endanger the health of the operator and also affect the quality of the surface by entangling the surface while the material is being machined.

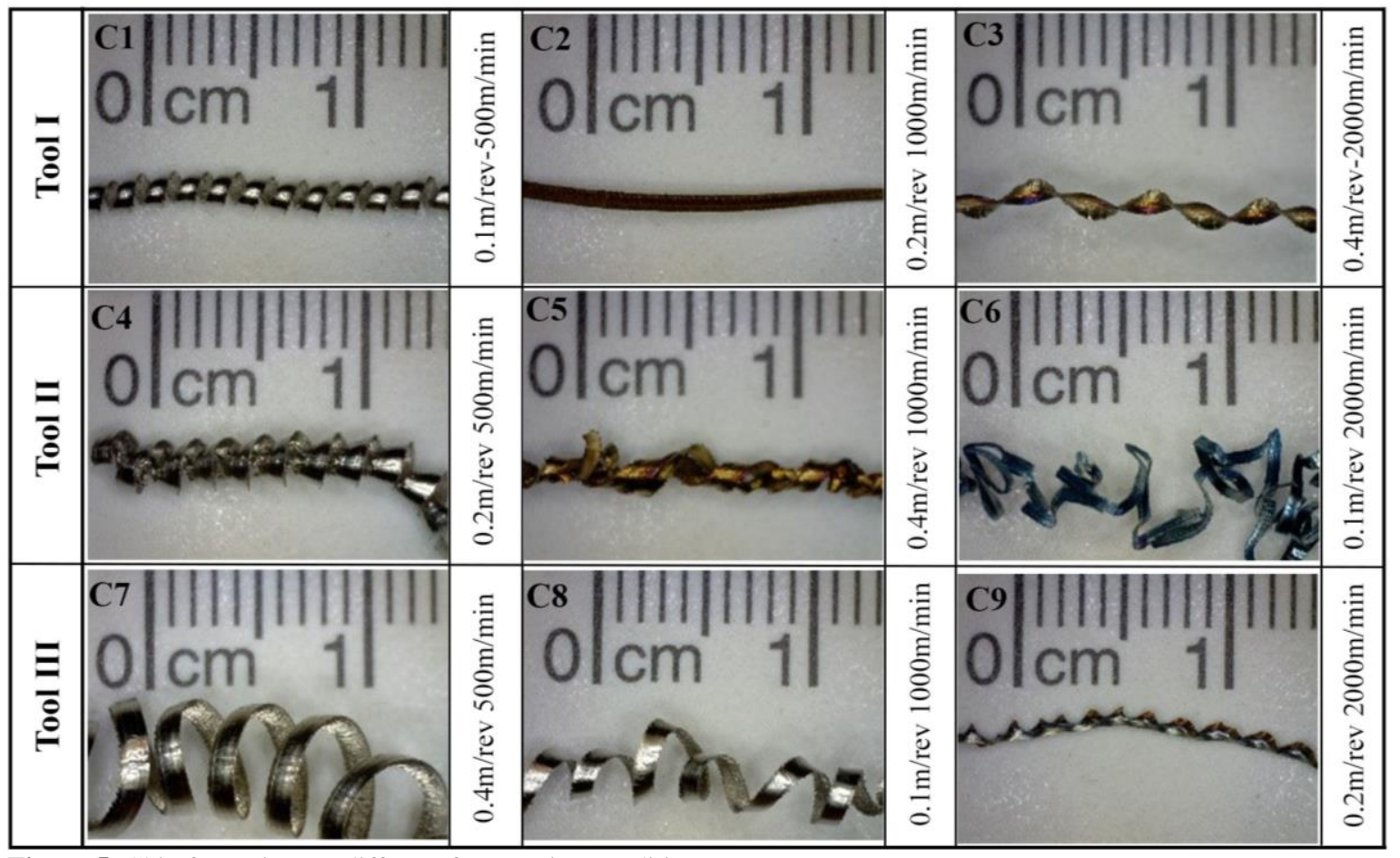

Figure 5. Chip formations at different face turning conditions 
Table 6. Types of chip formations obtained for different turning parameters

\begin{tabular}{c|c}
\hline Chip no: & Shape of chip formations \\
\hline C1 & Long tubular chips \\
\hline C2 & Ribbon chips \\
\hline C3 & Conical helical chips with small radius \\
\hline C4 & Long conical helical chips \\
\hline C5 & Long conical helical chips \\
\hline C6 & Tubular chips snarled \\
\hline C7 & Washer type helical chips with a medium radius \\
\hline C8 & Washer type helical chips with a small radius \\
\hline C9 & Conical helical chips with small radius \\
\hline
\end{tabular}

\section{CONCLUSIONS}

In this study, the effect of different parameters on the surface roughness of the Incoloy 825 during machining was applied. Also, tool wear and chip formations were investigated at different machining conditions. The results obtained from the experiment are presented below:

- The optimum parameter combination for the lowest Ra value was obtained using an analysis of the S/N ratio. The parameters for optimum $\mathrm{Ra}$ value and their levels are obtained as the Tools: Tool II, feed rate: $0.1 \mathrm{~mm} / \mathrm{rev}$ and the cutting speed: $1000 \mathrm{~m} / \mathrm{min}$.

- When the ANOVA results is examined, the feed rate is the most critical parameter on the Ra values of the Incoloy 825 workpiece, with a contribution ratio of $74.3 \%$. It was observed that the cutting speed and the tools were $12.5 \%$ and $8.9 \%$, respectively.

- In general, the surface roughness values of the Incoloy 825 are directly proportional to the change in feed rate. In other words, as the feed rate decreases, the surface roughness decreases and increases as the feed rate increases. Increment of the cutting speed by a certain amount increases the surface quality; it is seen that the surface quality deteriorates after a certain value. The results show that the tools used in the experiments do not have a very notable effect on the surface quality.

- When the surface roughness values and tool wear are examined together, the surface quality deteriorates with the increase of the feed rate. It appears that cutting speed and different tool inserts do not have a significant difference on surface roughness and tool wear. However, as high cutting speeds are reached, the amount of heat between the tool tip and the workpiece increases, causing both tool tip wear and deterioration of surface quality.

\section{ACKNOWLEDGMENTS}

This project with the code 2018-1-AP2-2832 is supported for financial by Mersin University Scientific Research Projects unit.

\section{BIBLIOGRAPHY}

[1] SARIKAYA, M., YILMAZ, V., GULLU, A., "Analysis of cutting parameters and cooling/lubrication methods for sustainable machining in turning of Haynes 25 superalloy", Journal of Cleaner Production, v. 133, pp. 172-181, 2016.

[2] TAMANG, S., CHANDRASEKARAN, M., SAHOO, A., "Sustainable machining: an experimental investigation and optimization of machining Inconel 825 with dry and MQL approach", Journal of the Brazilian Society of Mechanical Sciences and Engineering, v. 40, pp. 374, 2018.

[3] HUA, Y., LIU, Z., "Effects of cutting parameters and tool nose radius on surface roughness and work hardening during dry turning Inconel 718", The International Journal of Advanced Manufacturing Technology, pp. 1-10, 2018.

[4] PASHMFOROUSH, F., BAGHERINIA, R.D., "Influence of water-based copper nanofluid on wheel loading and surface roughness during grinding of Inconel 738 superalloy", Journal of Cleaner Production, v. 178, pp. 363-372, 2018.

[5] DHANANCHEZIAN, M., "Study the machinability characteristics of Nicked based Hastelloy C-276 under cryogenic cooling”, Measurement, v. 136, pp. 694-702, 2019. 
[6] GRZESIK, W., NIESŁONY, P., HABRAT, W., et al., "Investigation of tool wear in the turning of Inconel 718 superalloy in terms of process performance and productivity enhancement", Tribology International, v. 118, pp.337-346, 2018.

[7] CHEN, Z., ZHOU, J., PENG, R.L., et al., "Plastic Deformation and Residual Stress in High Speed Turning of AD730 7 TM Nickel-based Superalloy with PCBN and WC Tools", In: The 4th CIRP Conference on Surface Integrity, 440-445, Tianjin, China, 11th-13th July, Elsevier, 2018,

[8] MOTORCU, A.R., KUS, A., DURGUN, I., "The evaluation of the effects of control factors on surface roughness in the drilling of Waspaloy superalloy", Measurement, v. 58 pp. 394-408, 2014.

[9] PARIDA, A.K., MAITY, K. "Modeling of machining parameters affecting flank wear and surface roughness in hot turning of Monel-400 using response surface methodology (RSM)", Measurement, v. 137, pp. 375-381, 2019.

[10] EZUGWU, E., "Improvements in the machining of aero-engine alloys using self-propelled rotary tooling technique”, Journal of Materials Processing Technology, v. 185, pp. 60-71, 2007.

[11] EZUGWU, E., "Key improvements in the machining of difficult-to-cut aerospace superalloys", International Journal of Machine Tools and Manufacture, v. 45 pp. 1353-1367, 2005.

[12] KUMAR, R., SAHOO, A.K., MISHRA, P.C., et al., Measurement and machinability study under environmentally conscious spray impingement cooling assisted machining, Measurement, v. 135 pp. 913 927, 2019.

[13] GUPTA, M.K., MIA, M., PRUNCU, C.I., et al., "Parametric optimization and process capability analysis for machining of nickel-based superalloy", The International Journal of Advanced Manufacturing Technology, v. 102, pp. 3995-4009, 2019.

[14] MOREIRA, J., AVILA, R., GODOY, G., et al., "The effect of the cryogenic treatment on the machinability of hardened AISI 52100 bearing steel”, Materia-Rio De Janeiro, v. 14, pp. 932-945, 2009.

[15] ZHENG, G., XU, R., CHENG, X., et al., "Effect of cutting parameters on wear behavior of coated tool and surface roughness in high-speed turning of 300M", Measurement, v. 125 pp. 99-108, 2018.

[16] BALOS, S., RAJNOVIC, D., SIDJANIN, L., et al., "Tensile and fatigue properties, machinability and machined surface roughness of Al-Si-Cu alloys", Matéria (Rio de Janeiro), 24, 2019.

[17] EZUGWU, E., WANG, Z., MACHADO, A., "The machinability of nickel-based alloys: a review, Journal of Materials Processing Technology, v. 86, pp. 1-16, 1999.

[18] KUMAR, C.S., PATEL, S.K., "Application of surface modification techniques during hard turning: Present work and future prospects", International Journal of Refractory Metals and Hard Materials, v. 76, pp. 112-127, 2018.

[19] KUNTOĞLU, M., SAGLAM, H., "Investigation of progressive tool wear for determining of optimized machining parameters in turning", Measurement, v. 140, pp. 427-436, 2019.

[20] LIANG, X., LIU, Z., WANG, B., "State-of-the-art of surface integrity induced by tool wear effects in machining process of titanium and nickel alloys: A review", Measurement, 2018.

[21] RAJBONGSHI, S.K., SARMA, D.K., "Performance parameters studies in machining of AISI D2 steel with dot-textured, groove-textured \& non-textured cutting tool at the flank face", International Journal of Refractory Metals and Hard Materials, v. 83, pp. 104970, 2019.

[22] GUPTA, M., PRUNCU, C., MIA, M. et al., "Machinability investigations of Inconel-800 super alloy under sustainable cooling conditions”, Materials, v. 11, pp. 2088, 2018.

[23] PALANISAMY, A., SElVARAJ, T. "Optimization of Machining Parameters for Dry Turning of Incoloy 800H Using Taguchi-Based Grey Relational Analysis”, Materials Today: Proceedings, v. 5, pp. 7708-7715, 2018.

[24] JOSHI, K.K., "An Experimental Investigations in Turning of Incoloy 800 in Dry, MQL and Flood Cooling Conditions", Procedia Manufacturing, v. 20, pp. 350-357, 2018.

[25] LIU, G., HUANG, C., ZHU, H., et al., "The modified surface properties and fatigue life of Incoloy A286 face-milled at different cutting parameters", Materials Science and Engineering: A, v. 704, pp. 1-9, 2017.

[26] ESKANDARI, B., DAVOODI, B., GHORBANI, H., "Multi-objective optimization of parameters in turning of N-155 iron-nickel-base superalloy using gray relational analysis", Journal of the Brazilian Society of Mechanical Sciences and Engineering, v. 40, pp. 233, 2018.

[27] ANGAPPAN, P., THANGIAH, S., SUBBARAYAN, S., "Taguchi-based grey relational analysis for modeling and optimizing machining parameters through dry turning of Incoloy 800H", Journal of Mechanical Science and Technology, v. 31, pp. 4159-4165, 2017. 
[28] PALANISAMY, A., SELVARAJ, T. Optimisation of turning parameters on heat treated INCOLOY $800 \mathrm{H}$ using cryogenically treated CVD tool with grey-based entropy method, International Journal of Machining and Machinability of Materials, v. 20, pp. 401-424, 2018.

[29] PALANISAMY, A., SELVARAJ, T., SIVASANKARAN, S., "Optimization of Turning Parameters of Machining Incoloy $800 \mathrm{H}$ Superalloy Using Cryogenically Treated Multilayer CVD-Coated Tool”, Arabian Journal for Science and Engineering, pp. 1-14, 2018.

[30] THAKUR, A., GANGOPADHYAY, S., MAITY, K. et al., "Evaluation on effectiveness of CVD and PVD coated tools during dry machining of Incoloy 825”, Tribology Transactions, v. 59, pp. 1048-1058, 2016.

[31] VENKATESANA, K., DEVENDIRANB, S., GHAZALYC, N.M., et al., "Optimization of Cutting Parameters on turning of Incoloy $800 \mathrm{H}$ using Al2O3 Nanofluid in Coconut oil", Procedia Manufacturing, v. 30, pp. 268-275, 2018.

[32] REIS, B.C.M., et al., "Influence of cutting tool material on the machinability of ABNT 4340 steel in turning", Materia-Rio De Janeiro, v.24, 2019.

[33] EL-HOFY, H., Fundamentals of machining processes: conventional and nonconventional processes. CRC press, 2018.

[34] CAGAN, S.C., PRUNCU, C., BULDUM, B.B., "An investigation into ball burnishing process of magnesium alloy on CNC lathe using different environments", Journal of Magnesium and Alloys, v.8, pp. 1061-1070, 2020.

[35] DENIS, C., "Machining and metalworking handbook (McGraw-Hill Handbooks)", McGraw-Hill Professional, 2005.

[36] GROOVER, M.P., Fundamentals of modern manufacturing: materials, processes, and systems. John Wiley \& Sons, 2020.

[37] MIA, M., DHAR, N.R., "Optimization of surface roughness and cutting temperature in high-pressure coolant-assisted hard turning using Taguchi method", The International Journal of Advanced Manufacturing Technology, v. 88, pp. 739-753, 2017.

[38] MORELO, F., GRABARSKI M.I., · BELTRÃO P.A.C., et al. "Surface integrity of bored super duplex stainless steel SAF 2507”, Journal of the Brazilian Society of Mechanical Sciences and Engineering, v. 39, pp. 2649-2658, 2017.

[39] HE, C., ZONG, W., ZHANG, J. "Influencing factors and theoretical modeling methods of surface roughness in turning process: State-of-the-art", International Journal of Machine Tools and Manufacture, 2018.

[40] GUPTA, M.K., SOOD P.K. "Surface roughness measurements in NFMQL assisted turning of titanium alloys: An optimization approach" Friction, v. 5(2), pp. 155-170, 2017.

[41] MENDANHA REIS, B.C., SANTOS PEREIRA, N.F., SANTOS, A.J. et al., Influence of cutting tool material on the machinability of ABNT 4340 steel in turning, Materia-Rio De Janeiro, v. 24, 2019.

[42] CAGAN, S.C., BULDUM, B.B., OZKUL, I. "Experimental investigation on the ball burnishing of carbon fiber reinforced polymer", Materials and Manufacturing Processes, v. 34, pp. 1062-1067, 2019.

[43] BULDUM, B.B., CAGAN, S.C., "Study of Ball Burnishing Process on the Surface Roughness and Microhardness of AZ91D Alloy", Experimental Techniques, v. 42, pp. 233-241, 2017.

[44] OZKUL, I. "Ball burnishing process effects on surface rouhgness for al 6013 alloy", Turkish Journal of Engineering, v. 3, pp. 9-13, 2019.

[45] BULDUM, B.B. "Investigation of surface roughness and microhardness in ball burnishing process of AZ31B magnesium alloy”, Selcuk University Journal Engineering Science Technology, v.6, pp. 152-161, 2018.

[46] SHARMA, A.K., SINGH, R.K., DIXIT, A.R., et al., "Characterization and experimental investigation of Al2O3 nanoparticle based cutting fluid in turning of AISI 1040 steel under minimum quantity lubrication (MQL)", Materials Today: Proceedings, v. 3, pp. 1899-1906, 2016.

[47] RATH, D., PANDA, S., PAL, K., "Prediction of surface quality using chip morphology with nodal temperature signatures in hard turning of AISI D3 steel, Materials Today: Proceedings, v. 5, pp. 1236812375, 2018.

[48] PATHAN, A., KADAM, M., "Experimental study on effect of cutting parameters on chip-tool interface temperature and chip formation in turning EN-31 hardened steel under flooded and mql conditions", International Journal of Innovative Science Engineering and Technology, v. 2, pp. 724-729, 2015.

[49] ISO, 3685, Tool life testing with single-point turning tools, International Standard, (1993). 


\section{ORCID}

Suleyman Cinar CAGAN

Berat Baris BULDUM https://orcid.org/0000-0002-5552-2135

https://orcid.org/0000-0003-2855-2571 